\title{
Effect of Inulin on the Physical, Chemical and Sensory Quality Attributes of Polish Chicken Burgers
}

\author{
Aneta Cegiełka (Corresponding author) \\ Warsaw University of Life Sciences-SGGW \\ Department of Food Technology \\ Nowoursynowska 159c, Warsaw 02-776, Poland \\ Tel: 48-225-937-532Ｅ-mail: aneta_cegielka@sggw.pl
}

\author{
Krzysztof Tambor \\ Warsaw University of Life Sciences-SGGW \\ Analytical Center of SGGW \\ Ciszewskiego 8, Warsaw 02-786, Poland
}

Tel: 48-225-935-810 E-mail: krzysztof_tambor@sggw.pl

\author{
Received: November 18, 2011 \\ Accepted: November 29, $2011 \quad$ Published: February 1, 2012 \\ doi:10.5539/jfr.v1n1p169 \\ URL: http://dx.doi.org/10.5539/jfr.v1n1p169
}

The research was financed by the Polish Ministry of Science and Higher Education: Project No. N312 210936, in years 2009-2011.

\begin{abstract}
Four formulations of chicken burger were prepared: control product without inulin, and products with 1.0, 2.0 or $3.0 \%$ of inulin (in relation to the weight of meat, fatty raw material, and water), respectively. Physical, chemical and sensory analyses were made to evaluate the effect of inulin on the quality of cooked burgers. The results showed that the application of inulin did not cause significant decrease of the thermal processing yield nor the shear force of the products. However, the addition of inulin resulted in slight, but significant differences $(\mathrm{P}<$ 0.05 ) in chemical composition and energy value of burgers. Burgers of all formulations were acceptable in sensory characteristics. The addition level of inulin not higher than $1.0 \%$, did not result in deterioration of physical, chemical and sensory quality characteristics of chicken burgers. To improve the nutritional value of chicken burgers, the modification of fatty acid composition is recommended.
\end{abstract}

Keywords: chicken burgers, Inulin, Quality characteristics

\section{Introduction}

In recent years fast food and convenient-type products gained a permanent position on Polish market of processed meat products. Among them burgers are still very popular, and their commercial offer expanded with pork and poultry products. Analyses of meat burgers available on Warsaw (Poland) market showed that their quality was very diversified and mostly depended on the formula. For example, many of the products were relatively low in protein and high in saturated fat and cholesterol. The use of a wide range of non-meat additives was also common (Krygier \& Maksimowicz, 2008).

Contemporary consumers are increasingly looking for both traditional and convenient meat products with improved nutritional value. Manufacturing of "healthier" meat products is not always easy since they must taste good and be reasonably priced so that consumers will regularly purchase them (Decker \& Park 2010; Fernández-Ginéz \& others, 2005). To satisfy the needs of consumers producers may use different strategies. One of them is the incorporation of functional additives into processed meat products. Research results indicate that in production of burgers such additives as soy protein (Hoogenkamp, 1997), wheat fiber (Cegiełka \& Pęczkowska, 2008; Cegiełka \& Młynarczyk, 2010), lycopene (García \& others, 2009), folic acid (Galán \& others, 
2010), and plant oils (Forell \& others, 2010) can be applied.

Among novel ingredients used in food processing, a vegetable carbohydrate inulin offers a unique combination of nutritional properties and important technological benefits. Inulin-type fructans $[\beta-(2,1)$-fructans $]-$ industrially obtained from chicory roots - are both components of soluble dietary fiber and prebiotic food ingredients (Chawla \& Patil, 2010, Franck, 2002). The incorporation of inulin, due to its ability to bind water, form gel, and imitate the sensorial and technological properties of animal fat, allows upgrading of both taste and mouthfeel in a wide range of processed meat products. Although even the whole amount of animal fatty raw material could be replaced with $25 \%$ inulin gel in meat product formula, the substitution level is usually lower (Jánávary, 2005; Nitsch, 2006). The usefulness of rehydrated inulin (inulin gel) as a fat substitute was demonstrated in a wide range of processed meat products: scalded sausages (García \& others, 2006; Tröger \& others, 2005), canned meat products (Florowski \& Adamczak, 2010), meat balls (Flaczyk and others, 2009), liver pâté (Florowski \& others, 2008), and fermented sausages (Mendoza \& others, 2001). However, inulin, when applied as functional additive, that is dietary fiber or prebiotic ingredient - not a fat replacer - may help to improve the nutritional value without deterioration of sensorial characteristics of meat product (Beriain \& others, 2011; Ergönül \& others, 2009).

So far most studies on the application of inulin in meat processing were focused on substitution of animal fatty raw material with inulin gel. Furthermore, not much research was done on convenience meat products. Therefore, the aim of this study was to evaluate the effect of addition of inulin on the quality characteristics of burgers from chicken meat. Inulin was used as nutritionally functional additive, not as replacer of animal fatty raw material. This work is a part of the research project on improving the quality and shelf-life of chicken burgers with modified nutritional profile (that is formulated with different type of dietary fiber and enriched with plant oil). The obtained results should provide a basis for further research.

\section{Materials and Methods}

\subsection{Preparation of chicken burgers}

Raw materials for the preparation of burgers were collected from "SuperDrob" SA meat processing plant (Karczew, Poland). Chilled chicken meat (about $5 \mathrm{~kg}$ ) was purchased each time prior to the each replication of experiment. Chilled pork jowl (about $6 \mathrm{~kg}$ ) was purchased once, before the experiment started, then cut into pieces and coarse ground using a laboratory grinder (Mesko, Skarżysko-Kamienna, Poland). The ground meat was thoroughly mixed and divided into 4 portions, which were vacuum packed and frozen at $-28 \pm 2{ }^{\circ} \mathrm{C}$.

Four formulations of chicken burgers were manufactured. The composition of burgers differed by the addition level of inulin Orafti ${ }^{\circledR} H P X$ (Beneo-Orafti Ltd., Tienen, Belgium) (Table 1). Control product (PC) did not contain inulin. In burger formulations P1, P2, and P3, respectively, 1.0, 2.0, and 3.0 \% of inulin was incorporated. The addition level of inulin to the batter was calculated in relation to the weight of chicken meat, pork jowl, and water. The inulin was added to the batter in a rehydrated form ( 1 part of inulin powder: 3 parts of water), that is as a inulin gel. The gel was prepared about $24 \mathrm{~h}$ prior to the production of burgers, using water provided in the formula. Inulin powder was dissolved in water using an electric blender, and then the solution was heated to boiling. Heating was continued for a while until a clear solution was obtained. Inulin solution was chilled at a room temperature $\left(18 \pm 2{ }^{\circ} \mathrm{C}\right)$ for $60 \mathrm{~min}$, then placed in a laboratory refrigerator at $4 \pm 1{ }^{\circ} \mathrm{C}$.

About $24 \mathrm{~h}$ prior to the production of burgers pork jowl was thawed at $4 \pm 1{ }^{\circ} \mathrm{C}$. Directly before preparation of burgers, chicken thigh meat and pork jowl were ground using a laboratory grinder with a plate having 5-mm-dia orifices. Soy protein isolate SPI 733

(Solae ${ }^{\mathrm{TM}}$, St. Louis, Mo, U.S.A.) was rehydrated (1 part of dry preparation: 4 parts of water) using water provided in the recipe.

Batters were prepared in laboratory mixers (Kenwood Ltd., Havant, England). After mixing of chicken tight meat with table salt (about $5 \mathrm{~min}$ ) other ingredients were added: pork jowl, soy protein isolate, seasoning and depending on product formula - inulin gel and the remaining amount of water. Mixing was continued until ingredients were thoroughly distributed (about $15 \mathrm{~min}$ ). Burgers were formed to a shape of flat $100 \mathrm{-g}$ discs (about $9-\mathrm{cm}$ dia and $0.9-\mathrm{cm}$ thick) by use of manual mould. Burgers were frozen at $-28 \pm 2{ }^{\circ} \mathrm{C}$ for $30 \mathrm{~min}$ in order to maintain the shape. Then they were cooked on an electric grill (Unox S. p. A., Vigodarzere-Padova, Italy) equipped with two ceramic plates: upper and lower. Temperature of the plates was $200 \pm 5{ }^{\circ} \mathrm{C}$. Cooking was continued until the temperature of $72{ }^{\circ} \mathrm{C}$ was reached in the centre of the product (about $7 \mathrm{~min}$ ). Internal temperature was monitored using a portable skewer digital thermometer (Hanna Instruments ${ }^{\circledR}$, Woonsocket, RI, U.S.A.). Burgers were chilled at room temperature for $30 \mathrm{~min}$, and then in a laboratory refrigerator $\left(4 \pm 1^{\circ} \mathrm{C}\right)$. 
After about $24 \mathrm{~h}$ burgers were subjected to analyses. Measurement of texture, analysis of basic chemical composition, and evaluation of sensorial attributes of cooked burgers were carried out. Energy value of burgers was calculated. Fatty acid composition of burgers was determined in products manufactured in the last replication of experiment. The experiment was replicated four times on four different days using different batches of poultry meat and one batch of pork jowl.

\subsection{Determination of thermal processing yield}

Ten raw burgers from each formulation were weighted immediately after forming. After chilling the products to room temperature, the same burgers from each formulation were weighted again to measure the weight loss by the difference and to calculate the processing yield, which was expressed as percentage.

\subsection{Textural analysis}

The textural properties of cooked and chilled $\left(4 \pm 1{ }^{\circ} \mathrm{C}, 24 \mathrm{~h}\right)$ burgers were evaluated using the universal testing machine Zwicki 1120 (Zwick GmbH \& Co., Ulm, Germany) equipped with the Warner-Bratzler blade. Shear force $(\mathrm{N})$ - the maximum value of the force registered during moving the blade through the sample - was calculated at the speed of crosshead of $50 \mathrm{~mm} / \mathrm{min}$. The tests were carried out on cuboidal-shaped samples cut out of burgers $(3 \mathrm{~cm} \times 9 \mathrm{~cm} \times 0.9 \mathrm{~cm}$; width $\times$ length $\times$ height). Five replicates were measured from five burgers of each formulation. The reported results are calculated mean values.

\subsection{Chemical analyses}

Chemical analyses were carried out on cooked and chilled $\left(4 \pm 1{ }^{\circ} \mathrm{C}, 24 \mathrm{~h}\right)$ burgers according to Polish Standards. For chemical analyses three pieces of burgers of each formula were randomly collected and ground twice in an electric mini food grinder (Zelmer SA, Rzeszów, Poland) with a plate having 2-mm-dia orifices.

Moisture (g water $/ 100 \mathrm{~g}$ sample) was determined by drying a $3 \mathrm{~g}$ sample at $105^{\circ} \mathrm{C}$ to constant weight according to PN-ISO 1442: 2000 (Polish Standard, 2000b). Protein (g protein /100 g sample) was evaluated by Kjeldahl method in accordance with PN-A-84018: 1975 (Polish Standard, 1975) using a Kjeltec System 1026 Distilling Unit (Foss Tecator, Höganäs, Sweden). Fat (g fat /100 g sample) was assayed by Soxhlet method according to PN-ISO 1444: 2000 (Polish Standard, 2000c) using a Büchi Extraction System B-811 (Büchi Labortechnik AG, Flawil, Switzerland). Fat content was calculated by weight loss after a 30-cycle extraction with petroleum ether. Chlorides (g chlorides /100 g sample) were determined by Mohr method according to PN-A-82112: 1973 /AZ1:2002 (Polish Standard, 1973). Ashing of sample (g ash /100 g sample) was performed at $550{ }^{\circ} \mathrm{C}$ to constant weight according to PN-ISO 936: 2000 (Polish Standard, 2000a).

All determinations were performed in duplicate. The reported results are calculated mean values.

\subsection{Energy value calculation}

Energy value of burgers was calculated basing on the assayed content of protein and fat, and the assumed amount of the inulin addition. Energy conversion factors corresponding to protein and fat were based on the recommendation of Council Directive 90/496/EEC (1990). For $1 \mathrm{~g}$ of inulin - used as dietary fibre - energy conversion factor of $8 \mathrm{~kJ}(2 \mathrm{kcal})$ was adopted, which was consistent with the recommendations of the Commission Directive 2008/100/EC (2008).

\subsection{Analysis of fatty acid composition}

Fatty acid composition of chicken burgers was determined only ones, that is in products obtained in the last replication of experiment. The analyses of fatty acids were carried out in cooked and chilled $\left(4 \pm 1{ }^{\circ} \mathrm{C}, 24 \mathrm{~h}\right)$ products. The method modified by Folch and others (1957) was used for lipid extraction from product sample. One hundred milligrams of the obtained lipids was esterified to obtain fatty acid methyl esters (FAMEs). FAMEs were separated by gas chromatograph Agilent Technologies 7890A equipped with a split injector, capillary column Restek 2330 (length $105 \mathrm{~m}$, internal diameter. $0.25 \mathrm{~mm}$, film thickness $0.2 \mu \mathrm{m}$ ), flame ionization detector (FID), and work station. Analysis parameters were as follows: helium as carrier gas at a constant flow of $1,2 \mathrm{ml} / \mathrm{min}$, inlet and detector temperature: $250{ }^{\circ} \mathrm{C}$ and $300^{\circ} \mathrm{C}$ respectively, inlet split 1:50. The temperature of oven was programmed as follows: initial temperature was $100{ }^{\circ} \mathrm{C}$ for $4 \mathrm{~min}$, then rose to $240{ }^{\circ} \mathrm{C}$ at $3{ }^{\circ} \mathrm{C} / \mathrm{min}$. The final temperature of oven was held till the elution of the last peak on chromatogram. The FAMEs were indentified by comparing their retention times with those of the commercial standard FAMEs (Supelco 37 Component FAME Mix, Sigma-Aldrich, St. Louis, MO, U.S.A.). Quantification was as area percentages. The analyses of fatty acid composition were performed in duplicate in each sample. The mean values were calculated and expressed as the results. 


\subsection{Sensory evaluation}

Sensory evaluation of burgers was conducted in accordance with PN-ISO 4121: 1998 (Polish Standard, 1998). Burgers were evaluated by eight panelists, who were recruited from the stuff and students of the Warsaw Univ. for Fife Sciences-SGGW (Warsaw, Poland). All the panelists were experienced in sensory evaluation of meat products. The selection of assessors was based on recommendations of PN-ISO 8586-1: 1996 (Polish Standard, 1996). The analyses performed in individual booths under white fluorescent lights. The burger samples were served to the panelists immediately after warming up on the electric grill to an internal temperature of $55-60{ }^{\circ} \mathrm{C}$. Using a 10-point line scale $(0=$ very undesirable, 10 points $=$ very desirable $)$ the acceptability of colour, aroma, taste, hardness, juiciness, and consistency was evaluated. At the end of the test, panelists were asked to give a score for general quality of the products from 0 to 10 .

\subsection{Statistical analysis}

Statistical analysis (one-way analysis of variance) was applied to the data to determine differences $(\mathrm{P}<0.05)$. To discover where there were significant differences between the levels of the main factor, contrasts (Tukey test) between means were made. Pearson's correlation coefficient ( $r$ ) was calculated to determine the linear correlation between chosen quality attributes of chicken burgers. The statistical analyses were done using the statistical package Statgraphics Plus 4.1 (Manugistics, Inc. Rockville, MD., U.S.A.).

\section{Results and Discussion}

\subsection{Thermal processing yield and texture of chicken burgers}

The thermal processing yield of burgers of all formulations was approximately $80 \%$ (Table 2). Increasing the level of inulin did not significantly $(\mathrm{P}>0.05)$ decrease the yield of the products.

The obtained results were in agreement with results of other authors, who had applied inulin in order to improve the nutritional value and sensory characteristics of processed meat products. Ergönül and others (2009) found that the application of powdered inulin as a prebiotic ingredient to turkey meat balls did not increase the thermal loss. On the contrary, Beriain and others (2011) reported that inulin may affect the production yield of raw fermented low-salt sausages, due to slowing mass losses during ripening process.

In other studies inulin was used as the replacer of animal fatty raw material to lower the energy value of processed meat products. Substitution of animal fat with inulin gel usually caused an increase in cooking loss (that is decreased the production yield), what was found in canned meat products (Makała, 2003, Florowski \& Adamczak, 2010) and pâtés (Florowski \& others, 2008).

The addition of inulin did not differentiate significantly $(P>0.05)$ the shear force of burgers (Table 2). Only the slight decrease of this texture parameter was found with increasing addition level of inulin. The insignificant differences in shear force of cooked burgers may be explained by the fact, that inulin was not used as the substitute of animal fatty raw material. That means that no additional quantity of water was added to the meat batters.

The results obtained in this work agreed with results published by Ergönül and others (2009) who reported no negative effect of inulin - when used as a prebiotic - on instrumentally measured hardness of meat balls. However, addition of 2.5 or $5.0 \%$ of powdered inulin into the batter caused a slight increase of hardness, when compared to the control product. Mendoza and others (2001) also found that addition of inulin did not affect hardness of raw sausage, but might decrease springiness of the final product. However, textural analysis conducted by García and others (2006) indicated that application of powdered inulin increased hardness in both low-fat and full-fat mortadella. When inulin was incorporated into the meat batters as a gel (that is in rehydrated form), the sausages were softer than the control products.

It should be noted that inulin may have a significant influence on the texture of processed meat products, especially when it is used for replacement of animal fatty raw material in the recipe. Florowski and Adamczak (2010) found the decrease of instrumentally measured hardness, cohesiveness, springiness and chewiness of canned meat products formulated with different quantities of inulin gel. Makała (2003) also reported that partial replacement of animal fatty raw material may change the rheological parameters of canned meat product, for example plasticity, but not slice strength.

\subsection{Chemical analyses and energy value of chicken burgers}

Compositional analysis of chicken burgers revealed slight differences in all the chemical components (Table 3). Except for chlorides, increasing the level of inulin in the formula significantly $(\mathrm{P}<0.05)$ increased the content of moisture and ash, and decreased $(\mathrm{P}<0.05)$ the content of fat and protein, when compared with control product 
(PC). The differences for chemical components between the four burger formulations were most likely due to effect of inulin on the thermal processing yield. However, no significant correlation between moisture content and thermal processing yield was found in this study.

The results obtained in this study are similar to results of Beriain and others (2011) who found that addition of inulin - used as nutritional additive - may slightly, but significantly decrease the content of fat and protein, and increase the moisture content of raw fermented sausage. Although the ripening process of sausages formulated with inulin was not disturbed, the drying process was slowed down. On the contrary, Ergönül and others (2009) reported that the application of inulin did not significantly differentiate the content of moisture, protein, and fat in baked turkey meat balls in comparison to the control product.

As it was found in other studies, incorporation of inulin into the formula of processed meat product may significantly differentiate its chemical composition, especially when animal fatty raw material is replaced with inulin gel. As had been expected, the inverse relation between content of fat and moisture was observed in different types of meat products formulated with inulin: pork meat balls (Flaczyk \& others, 2009), mortadella (Brauer, 2005; García \& others, 2006; Nowak \& others, 2007), scalded and liver sausages (Nitsch 2006, Tröger \& others, 2005), baked pâté (Florowski \& others, 2008), canned pork product (Makała, 2003) and dry fermented sausage (Mendoza \& others, 2001).

Although in this study inulin was not used as the partial substitute of animal fatty raw material, that is the quantity of the pork jowl was the same in all burger formulations (Table 1), the energy value of chicken burgers decreased significantly $(\mathrm{P}<0.05)$ with increasing the level of inulin to $2.0 \%$ or more (Table 4$)$. The reduction of the energy value did not exceed $7 \%$ in product $\mathrm{P} 3$ when compared with the control product (PC). The differences for energy values of burgers may be explained by differences in thermal loss and chemical composition between all the four product formulations. The obtained results should provide a basis for further research.

The results obtained by Makała (2003), Brauer (2005), Nowak and others (2007), and Flaczyk and others (2009) showed that the energy value of processed meat products may be reduced to a much higher extent (even up to $70 \%$ ), provided that the inulin gel is used to replace the animal fatty raw material in the formula.

\subsection{Fatty acid composition of chicken burgers}

The aim of the fatty acid composition analysis was to obtain the preliminary results for further research into improvement of the nutritional value of this chicken burgers. One of the objectives of the research project is to modify the fatty acid composition of burgers according to the recommendations of dietary guidelines.

The obtained results indicated that independent of the inulin addition level the burgers were characterized by similar content of all the groups of fatty acids (Table 5). In burgers of all the four formulations palmitic acid (C16:0) and stearic acid (C18:0) dominated among saturated fatty acids (SFAs). Palmitic acid is - in addition to myristic acid (C14:0) and lauric acid (C12:0) - used by the human organism for the synthesis of cholesterol, why the stearic acid has a neutral effect on blood cholesterol level (Simopoulos, 2000).

All the products were quite rich in unsaturated fatty acids (UFAs). In burgers of all formulations oleic acid (C18:1) dominated among monounsaturated fatty acids (MUFA), whereas the main polyunsaturated fatty acids (PUFAs) were: linoleic acid (C18:2, n-6) and $\alpha$-linolenic acid (C18:3, n-3). The PUFAs are important components of all cell membranes in the human body. The two classes of PUFA: $n-6$ and n-3 have opposing physiological functions. Therefore, their balance is important for homeostasis, normal growth and development (Simopoulos, 2000). The ratio of PUFAs to SFAs, and the ratio of PUFAs n-6 to PUFAs n-3 are often used to characterize the nutritional value of lipids in foods. As recommended, these ratios should not be lower than 0.4, and not exceed 4.0, respectively (Givens \& others, 2006). The obtained results suggest that the nutritional value of fat of chicken burgers might be improved, in terms of the relationship between PUFAs n- 6 and PUFAs n-3. Due to the deficiency of PUFAs n-3 in the diet of average European, nutritionists postulate to increase consumption of food products both naturally rich in PUFAs n-3 and enriched with these components (Dybkowska \& others, 2004, Givens \& others, 2006).

Lack of information about the effect of inulin on fatty acid profile of processed meat products may be explained by fact that the application of inulin is not intended to modify the composition of fatty acids, but rather to lower the energy value of the product and to give the product the acceptable sensorial characteristics. Jiménez-Colmenero (2007) points out that useful method for improving the fatty acid profile of processed meat products is, for example, partial substitution of the animal fatty raw material with plant oil. In products enriched with oil inulin may help to achieve the desired sensory quality, what was confirmed by Beriain and others (2011) in raw fermented sausages. 


\subsection{Sensory evaluation of chicken burgers}

The results of sensory evaluation of burgers showed that products of all the formulations were acceptable in sensory characteristics (Table 6). The application of inulin slightly, but significantly $(\mathrm{P}<0.05)$ differentiated all the sensory attributes of burgers. In comparison to control product (PC), burgers formulated with 1.0 or $2.0 \%$ of inulin (formulations $\mathrm{P} 1$ and $\mathrm{P} 2$, respectively) were scored significantly $(\mathrm{P}<0.05)$ better for color, aroma and taste.

The products PC and P1 were scored significantly better $(\mathrm{P}<0.05)$ for hardness than the two others, what means that the addition level of inulin higher than $1.0 \%$ had negative effect on the hardness of burgers. Decrease of shear force of burgers with increasing addition level of inulin to the batter was detected by the panelists. However, there was no significant relationships $(r=0,31)$ between the hardness and the instrumentally measured shear force of chicken burgers.

Addition of inulin gel did not enhance the acceptability of juiciness of burgers. On the contrary, juiciness of the products $\mathrm{P} 1, \mathrm{P} 2$, and $\mathrm{P} 3$ deteriorated slightly, but significantly $(\mathrm{P}<0.05)$ in comparison to the control product. The panelists found burgers with inulin to be "too watery". The juiciness of burgers was negatively, but not significantly correlated with the water content in products $(\mathrm{r}=-0,18)$.

The products $\mathrm{PC}$ and $\mathrm{P} 1$ got the highest general quality scores in the sensory evaluation, being scored significantly $(\mathrm{P}<0.05)$ better than the two others. The results also indicated that the product with $1.0 \%$ of inulin was scored the highest notes for the five sensory attributes.

Ergönül and others (2009) also reported that addition of inulin did not decreased the general sensory quality of turkey meat balls. The results of other studies showed that inulin - when used as the animal fatty raw material replacer - may have negative effect on sensorial characteristics of processed meat products (Jánávary, 2005; Makała, 2003). On the contrary, Florowski and others (2008), and Flaczyk and others (2009) found the positive effect of animal fat replacement with inulin on the juiciness of pâtés and the texture of meat pork meat balls, respectively.

\section{Conclusion}

In conclusion, acceptable chicken burgers with $1.0 \%$ of inulin (addition level as powdered inulin in relation to the weight of meat, fatty raw material, and water) can be produced. The application of inulin did not cause significant decrease of the thermal processing yield nor the shear force of the products. Although all the burgers were sensory acceptable, the product with $1.0 \%$ of inulin was scored the highest notes for the color, aroma, taste, hardness, and juiciness. To improve the nutritional value of burgers the modification of fatty acid profile is also recommended.

\section{References}

Beriain, M. J., Gómez, I., Petri, E., Insausti, K., \& Sarriés, M. V. (2011). The effect of olive oil emulsified alginate on the physico-chemical, sensory, microbial, and fatty acid profiles of low-salt, inulin-enriched sausages. Meat Science, 88(1), 189-197. http://dx.doi.org/10.1016/j.meatsci.2010.12.024

Brauer, H. (2005). Fettarm and ballaststoffreich. Fleischwirtschaft, 85(1), 39-40.

Cegiełka, A., \& Młynarczyk, K. (2010). The effect of addition of the wheat fibre Vitacel WF 400 on the quality of chicken hamburgers. Nauka Przyroda Technologie [Online] Available: http://www.npt.up-poznan.net/pub/art._4_55.pdf (July 27, 2010).

Cegiełka, A., \& Pęczkowska, M. (2008). Effect of addition of wheat fibre preparation on quality of poultry meat hamburgers. Roczniki Instytutu Przemystu Mięsnego i Ttuszczowego, 46(2),75-82.

Chawla, R., \& Patil, G. R. (2010). Soluble dietary fiber. Comprehensive Reviews in Food Science and Food Safety, 9(2), 178-196. http://dx.doi.org/10.1111/j.1541-4337.2009.00099.x

Commission Directive 2008/100/EC of 28 October 2008 amending Council Directive 90/496/EEC on nutrition labelling for foodstuffs as regards recommended daily allowances, energy conversion factors and definitions. Official Journal of European Union, L 285:9-12. October 10, 2008.

Council Directive of 24 September 1990 on nutrition labelling for foodstuffs (90/496/EEC). Official Journal of the European Communities L 276:40-44. October 6, 1990.

Decker, E. A., \& Park, Y. (2010). Healthier meat products as functional foods. Meat Science, 86(1), 49-55. http://dx.doi.org/10.1016/j.meatsci.2010.04.021

Dybkowska, E., Waszkiewicz-Robak, B., \& Świderski, F. (2004). Assessment of n-3 and n-6 polyunsaturated 
fatty acid intake in the average Polish diet. Polish Journal of Food Nutrition and Sciences, 13/54(4), 409-414.

Ergönül, B., Günç, P., Ergönül, P. G., \& Obuz, E. (2009). Funktionelle Eigenschaften prebiotischer Zutaten in Fleischprodukten. Fleischwirtschaft, 89(2), 140-143.

Fernández-Ginéz, J. M., Fernández-Lopéz, J., Sayas-Barberá, E., \& Pérez-Alvarez, J. A. (2005). Meat products as functional foods: a review. Journal of Food Science, 70(2), R37-R43.

Flaczyk, E., Górecka, D., Kobus, J., \& Szymander-Buszka, K. (2009). The influence of inulin addition as fat substitute on reducing energy value and consumer acceptance of model pork meatballs. Żywność. Nauka. Technologia. Jakość, 16(4), 41-46.

Florowski, T., \& Adamczak, L. (2010). Influence of fat replacement with inulin on selected quality traits of model canned meat products. Zeszyty Problemowe Postępów Nauk Rolniczych, (553), 91-98.

Florowski, T., Adamczak, L., Fuertez-Hernández, I., Moreno-Franco, M. B., \& Tyburcy, A. (2008). Effect of fat replacement by inulin on quality of baked poultry liver pâté. Roczniki Instytutu Przemystu Mięsnego $i$ Ttuszczowego, 46(2), 119-126.

Folch, J., Lees, M., \& Sloane, Stanley, G. H. (1957). A simple method for the isolation and purification of total lipids from animal tissues. Journal of Biological Chemistry, 226(1), 497-509.

Forell, S. C. P, Ranalli, N., Zaritzky, N. E., Andrés, S. C., \& Califano, A. N. (2010). Effect of type of emulsifiers and antioxidants on oxidative stability, colour and fatty acid profile of low-fat beef burgers enriched with unsaturated fatty acids and phytosterols. Meat Science, 86(2), 364-370. http://dx.doi.org/10.1016/j.meatsci.2010.05.015

Franck, A. (2002). Technological functionality of inulin and oligofructose. British Journal of Nutrition, 87(Suppl. 2), S287-S291. http://dx.doi.org/10.1079/BJN/2002550

Galán, I., García, M. I., \& Selgas, M. D. (2010). Effects of irradiation on hamburgers enriched with folic acid. Meat Science, 84(3), 437-443. http://dx.doi.org/10.1016/j.meatsci.2009.09.013

García, M. L, Calvo, M. M., \& Selgas, M. D. (2009). Beef hamburgers enriched in lycopene using dry tomato peel as ingredient. Meat Science, 83(1), 45-49. http://dx.doi.org/10.1016/j.meatsci.2009.03.009

García, M. L., Cáceres, E., \& Selgas, M. D. (2006). Effect of inulin on the textural and sensory properties of mortadella, a Spanish cooked meat product. International Journal of Food Science and Technology, 41, 1207-1215. http://dx.doi.org/10.1111/j.1365-2621.2006.01186.x

Givens, D. I., Kliem, K. E., \& Gibbs, R. A. (2006). The role of meat as a source of n-3 polyunsaturated fatty acids in the human diet. Meat Science, 74(1), 209-218. http://dx.doi.org/10.1016/j.meatsci.2006.04.008

Hoogenkamp, H. W. (1997). Nach Rezeptur hergestellte Hamburger. Fleischwirtschaft, 77(10), 906-910.

Jánávary, L. (2005). Ballaststoff als Fettersatz. Fleischwirtschaft, 85(2), 22-23.

Jiménez-Colmenero, F. (2007). Healthier lipid formulation approaches meat-based functional foods: Technological options for replacement of meat fats by non-meat fats. Trends in Food Science and Technology, 18(11), 567-578. http://dx.doi.org/10.1016/j.tifs.2007.05.006

Krygier, K., \& Maksimowicz, K. (2008). Jakość hamburgerów dostępnych na polskim rynku. Przemyst Spożywczy, 62(1), 27-29.

Makała, H. (2003). Effect of potato and wheat cellulose and inulin preparations on physicochemical characteristics and rheological properties of model meat preserves. Żywność. Nauka. Technologia. Jakość, 10(3), 21-30.

Mendoza, E., García, M. L, Casas, C., \& Selgas, M. D. (2001). Inulin as fat substitute in low fat, dry fermented sausages, Meat Science, 57(4), 387-393. http://dx.doi.org/10.1016/S0309-1740(00)00116-9

Nitsch, P. (2006). Sensorische Qualität bleibt erhalten: Technologie der Verarbeitung von Inulin als "Fettersatzstoff" in Brüh- und Kochwurst. Fleischwirtschaft, 86(11), 41-46.

Nowak, B., Von Mueffling, T., Grotheer, J., Klein, G., \& Watkinson, B. M. (2007). Energy content, sensory properties, and microbiological shelf life of German bologna-type sausages produced with citrate or phosphate and with inulin as fat replacer. Journal of Food Science, 72(9), S629-S638http://dx.doi.org/10.1111/j.1750-3841.2007.00566.x.

Polish Standard. (1973). PN-A-82112: 1973 /AZ1:2002. Meat and meat products. Determination of chloride 
content. Warsaw: Polish Committee for Standardization (3 p).

Polish Standard. (1975). PN-A-04018: 1975. Agricultural food products. Determination of nitrogen by Kjeldahl method and expressing as protein. Warsaw: Polish Committee for Standardization (11 p).

Polish Standard. (1996). PN-ISO 8586-1: 1996. Sensorial analysis. General guidance for the selection, training and monitoring of assessors. The selected assessors. Warsaw: Polish Committee for Standardization (24 p.)

Polish Standard. (1998). PN-ISO 4121: 1998. Sensorial analysis. Methodology. Valuation of foodstuffs using scaling methods. Warsaw: Polish Committee for Standardization (12 p).

Polish Standard. (2000a). PN-ISO 936: 2000. Meat and meat products. Determination of total ash. Warsaw: Polish Committee for Standardization (8 p).

Polish Standard. (2000b). PN-ISO 1442: 2000. Meat and meat products. Determination of moisture content (Reference method). Warsaw: Polish Committee for Standardization (3 p).

Polish Standard. (2000c). PN-ISO 1444: 2000. Meat and meat products. Determination of free fat content. Warsaw: Polish Committee for Standardization (7 p).

Simopoulos, A. P. (2000). Human requirement for N-3 polyunsaturated fatty acids. Poultry Science, 79(7), 961-970.

Tröger, K., Nitsch, P., Müller, W. P., \& Münch, S. (2005). Kein Angriff auf Geschmack und Textur: Funktionelle Fleischerzeugisse: Ein Beitrag zur gesunden Ernährung? Fleischwirtschaft, 85(7), 54-56.

\section{Notes}

Note $1 .{ }^{\mathrm{a}}$ in relation to the mass of chicken meat and pork jowl (total raw materials).

Note 2. ${ }^{\mathrm{b}}$ in relation to the mass of chicken meat, pork jowl and water for the above table.

Table 1. Formulations of chicken burgers

\begin{tabular}{|c|c|c|c|c|}
\hline \multirow{2}{*}{ Ingredient } & \multicolumn{4}{|c|}{ Formulations of burgers } \\
\hline & $\mathrm{PC}$ & $\mathrm{P} 1$ & $\mathrm{P} 2$ & P3 \\
\hline Chicken thigh meat (\%) & 85.0 & 85.0 & 85.0 & 85.0 \\
\hline Pork jowl (\%) & 15.0 & 15.0 & 15.0 & 15.0 \\
\hline Total raw materials (\%) & 100.0 & 100.0 & 100.0 & 100.0 \\
\hline Water $^{\mathrm{a}}(\%)$ & 15.0 & 15.0 & 15.0 & 15.0 \\
\hline Sodium chloride $^{\mathrm{b}}(\%)$ & 1.8 & 1.8 & 1.8 & 1.8 \\
\hline Soy protein isolate ${ }^{\mathrm{b}}(\%)$ & 1.5 & 1.5 & 1.5 & 1.5 \\
\hline Black \& herbal pepper mixture ${ }^{b}(\%)$ & 0.3 & 0.3 & 0.3 & 0.3 \\
\hline $\operatorname{Inulin}^{\mathrm{b}}(\%)$ & - & 1.0 & 2.0 & 3.0 \\
\hline
\end{tabular}

Table 2. Thermal processing yield and shear force of chicken burgers

\begin{tabular}{|l|l|l|}
\hline Formulations of burgers & Thermal processing yield $(\%) \pm \mathrm{SD}$ & Shear force $(\mathrm{N}) \pm \mathrm{SD}$ \\
\hline PC & $81.9 \mathrm{a} \pm 1.6$ & $29.1 \mathrm{a} \pm 3.8$ \\
\hline P1 & $81.0 \mathrm{a} \pm 1.7$ & $29.1 . \mathrm{a} \pm 4.0$ \\
\hline P2 & $80.2 \mathrm{a} \pm 1.2$ & $27.5 \mathrm{a} \pm 5.8$ \\
\hline P3 & $78.8 \mathrm{a} \pm 2.1$ & $27.2 \mathrm{a} \pm 5.3$ \\
\hline
\end{tabular}

PC - control product, P1 - product with $1.0 \%$ of inulin, P2 - product with $2.0 \%$ of inulin,. P3 - product with $3.0 \%$ of inulin.

Values in the same column bearing the same letters are not significantly different $(P>0.05)$;

SD - Standard Deviation. 
Table 3. Chemical composition of chicken burgers

\begin{tabular}{|l|l|l|l|l|l|}
\hline $\begin{array}{l}\text { Formulations } \\
\text { of burgers }\end{array}$ & $\begin{array}{l}\text { Moisture (\%) } \\
\pm \mathrm{SD}\end{array}$ & $\begin{array}{l}\text { Protein (\%) } \\
\pm \mathrm{SD}\end{array}$ & $\begin{array}{l}\text { Fat (\%) } \\
\pm \mathrm{SD}\end{array}$ & $\begin{array}{l}\text { Chlorides (\%) } \\
\pm \mathrm{SD}\end{array}$ & $\begin{array}{l}\text { Ash (\%) } \\
\pm \mathrm{SD}\end{array}$ \\
\hline PC & $63.9 \mathrm{a}$ & $19.3 \mathrm{c}$ & $12.8 \mathrm{c}$ & $2.2 \mathrm{a}$ & $1.7 \mathrm{a}$ \\
& \pm 0.60 & \pm 0.32 & \pm 0.06 & \pm 0.05 & \pm 0.17 \\
\hline P1 & $64.5 \mathrm{ab}$ & $18.4 \mathrm{~b}$ & $12.5 \mathrm{bc}$ & $2.1 \mathrm{a}$ & $2.0 \mathrm{ab}$ \\
& \pm 0.36 & \pm 0.24 & \pm 0.30 & \pm 0.06 & \pm 0.16 \\
\hline P2 & $64.8 \mathrm{~b}$ & $17.8 \mathrm{ab}$ & $12.1 \mathrm{~b}$ & $2.2 \mathrm{a}$ & $2.3 \mathrm{~b}$ \\
& \pm 0.26 & \pm 0.38 & \pm 0.25 & \pm 0.08 & \pm 0.12 \\
\hline P3 & $65.1 \mathrm{~b}$ & $17.5 \mathrm{a}$ & $11.5 \mathrm{a}$ & $2.0 \mathrm{a}$ & $2.5 \mathrm{~b}$ \\
& \pm 0.26 & \pm 0.31 & \pm 0.37 & \pm 0.05 & \pm 0.23 \\
\hline
\end{tabular}

PC - control product, P1 - product with $1.0 \%$ of inulin, P2 - product with $2.0 \%$ of inulin,. P3 - product with $3.0 \%$ of inulin.

Values in the same column bearing the same letters are not significantly different $(\mathrm{P}>0.05)$;

SD - Standard Deviation.

Table 4. Energy value of chicken burgers

\begin{tabular}{|l|l|l|}
\hline $\begin{array}{l}\text { Formulations } \\
\text { of burgers }\end{array}$ & Energy value $(\mathrm{kJ} / 100 \mathrm{~g}) \pm \mathrm{SD}$ & Caloric value $(\mathrm{kcal} / 100 \mathrm{~g}) \pm \mathrm{SD}$ \\
\hline $\mathrm{PC}$ & $803.6 \mathrm{c} \pm 3.54$ & $192.9 \mathrm{c} \pm 0.82$ \\
\hline $\mathrm{P} 1$ & $775.7 \mathrm{bc} \pm 8.61$ & $188.6 \mathrm{bc} \pm 2.09$ \\
\hline P2 & $754.3 \mathrm{ab} \pm 4.89$ & $184.1 \mathrm{ab} \pm 1.59$ \\
\hline P3 & $734.9 \mathrm{a} \pm 2,66$ & $179.3 \mathrm{a} \pm 4.40$ \\
\hline
\end{tabular}

PC - control product, P1 - product with $1.0 \%$ of inulin, P2 - product with $2.0 \%$ of inulin,. P3 - product with $3.0 \%$ of inulin.

Values in the same column bearing the same letters are not significantly different $(\mathrm{P}>0.05)$;

SD - Standard Deviation. 
Table 5. Fatty acid composition of chicken burgers (values are expressed as $\mathrm{g} / 100 \mathrm{~g}$ total fatty acids)

\begin{tabular}{|l|l|l|l|l|}
\hline \multirow{2}{*}{ Fatty acid/ Fatty acid group } & \multicolumn{4}{l}{ Formulations of burgers } \\
\cline { 2 - 5 } & PC & P1 & P2 & P3 \\
\hline C16:0 & 21.74 & 22.05 & 21.93 & 21.94 \\
\hline C18:0 & 9.95 & 10.79 & 10.56 & 10.13 \\
\hline Total saturated fatty acids (SFAs) & 33.52 & 34.74 & 34.46 & 33.93 \\
\hline C18:1 trans-9 & 0.22 & 0.26 & 0.25 & 0.23 \\
\hline C18:1 cis-9 Oleic & 40.32 & 40.30 & 40.62 & 40.23 \\
\hline C20:1 cis-11 & 0.77 & 0.78 & 0.79 & 0.76 \\
\hline $\begin{array}{l}\text { Total monounsaturated fatty acids } \\
\text { (MUFAs) }\end{array}$ & 44.64 & 44.29 & 44.69 & 44.46 \\
\hline C18:2 all,cis-9,12(n-6) Linoleic & 13.37 & 12.81 & 12.97 & 13.71 \\
\hline C18:3 all,cis-6,9,12(n-6) & 0.10 & 0.09 & 0.09 & 0.09 \\
\hline C18:3 all,cis-9,12,15(n-3) $\alpha$-Linolenic & 1.14 & 0.84 & 0.91 & 1.12 \\
\hline C20:2 all,cis-11,14(n-6) & 0.62 & 0.65 & 0.67 & 0.64 \\
\hline C20:3 all,cis-8,11,14(n-6) & 0.12 & 0.13 & 0.12 & 0.11 \\
\hline C20:3 all,cis-11,14,17(n-3) & 0.11 & 0.11 & 0.12 & 0.12 \\
\hline C20:4 all,cis-5,8,11,14(n-6) & 0.71 & 0.84 & 0.65 & 0.51 \\
\hline C20:5 all, cis-5,8,11,14,17(n-3) EPA & 0.05 & n.d. & n.d. & 0.05 \\
\hline C22:6 all,cis-4,7,10,13,16,19(n-3) DHA & 0.13 & n.d. & n.d. & 0.10 \\
\hline $\begin{array}{l}\text { Total polyunsaturated fatty acids } \\
\text { (PUFAs) }\end{array}$ & 16.35 & 15.52 & 15.58 & 16.54 \\
\hline Total unsaturated fatty acids (UFAs) & 60.99 & 59.81 & 60.27 & 61.00 \\
\hline PUFAs : SFAs & 0.49 & 0.47 & 0.45 & 0.49 \\
\hline PUFAs $n$-6 & 14.92 & 14.52 & 15.20 & 15.06 \\
\hline PUFAs $n$-3 & 1.43 & 0.95 & 1.03 & 1.48 \\
\hline PUFAs $n$-6 $:$ PUFAs $n$-3 & 10.43 & 15.28 & 14.76 & 10.17 \\
\hline
\end{tabular}

PC - control product, P1 - product with $1.0 \%$ of inulin, P2 - product with $2.0 \%$ of inulin,. P3 - product with $3.0 \%$ of inulin.

n.d. - not detected (the content of the fatty acid was lower than $0.05 \mathrm{~g}$ animal fatty raw material $/ 100 \mathrm{~g}$ of total fatty acids).

Table 6. Sensory evaluation of chicken burgers

\begin{tabular}{|l|l|l|l|l|l|l|}
\hline $\begin{array}{l}\text { Formulations } \\
\text { of burgers }\end{array}$ & $\begin{array}{l}\text { Color } \\
\pm \mathrm{SD}\end{array}$ & $\begin{array}{l}\text { Aroma } \\
\pm \mathrm{SD}\end{array}$ & $\begin{array}{l}\text { Taste } \\
\pm \mathrm{SD}\end{array}$ & $\begin{array}{l}\text { Hardness } \\
\pm \mathrm{SD}\end{array}$ & $\begin{array}{l}\text { Juiciness } \\
\pm \mathrm{SD}\end{array}$ & $\begin{array}{l}\text { General } \\
\text { quality } \\
\pm \mathrm{SD}\end{array}$ \\
\hline $\mathrm{PC}$ & $\begin{array}{l}6.0 \mathrm{a} \\
\pm 0.12\end{array}$ & $\begin{array}{l}6.6 \mathrm{a} \\
\pm 0.12\end{array}$ & $\begin{array}{l}5.9 \mathrm{a} \\
\pm 0.09\end{array}$ & $\begin{array}{l}6.9 \mathrm{c} \\
\pm 0.09\end{array}$ & $\begin{array}{l}7.1 \mathrm{~b} \\
\pm 0.09\end{array}$ & $\begin{array}{l}6.5 \mathrm{a} \\
\pm 0.33\end{array}$ \\
\hline $\mathrm{P} 1$ & $6.4 \mathrm{~b}$ & $7.0 \mathrm{~b}$ & $6.6 \mathrm{~b}$ & $7.0 \mathrm{c}$ & $6.9 \mathrm{a}$ & $6.4 \mathrm{a}$ \\
& \pm 0.14 & \pm 0.08 & \pm 0.08 & \pm 0.08 & \pm 0.09 & \pm 0.31 \\
\hline $\mathrm{P} 2$ & $6.3 \mathrm{~b}$ & $6.9 \mathrm{~b}$ & $6.4 \mathrm{~b}$ & $6.6 \mathrm{~b}$ & $6.8 \mathrm{a}$ & $6.2 \mathrm{~b}$ \\
& \pm 0.09 & \pm 0.08 & \pm 0.26 & \pm 0.13 & \pm 0.08 & \pm 0.20 \\
\hline $\mathrm{P} 3$ & $6.2 \mathrm{~b}$ & $6.9 \mathrm{~b}$ & $6.1 \mathrm{a}$ & $6.4 \mathrm{a}$ & $6.8 \mathrm{a}$ & $6.2 \mathrm{~b}$ \\
& \pm 0.17 & \pm 0.09 & \pm 0.19 & \pm 0.11 & \pm 0.08 & \pm 0.21 \\
\hline
\end{tabular}

PC - control product, P1 - product with $1.0 \%$ of inulin, P2 - product with $2.0 \%$ of inulin,. P3 - product with $3.0 \%$ of inulin.

Values in the same column bearing the same letters are not significantly different $(\mathrm{P}>0.05)$;

SD - Standard Deviation. 